\title{
Investigation of Crater Formation on Coatings via Combination of SEM- EDX and FT-IR Microscopy
}

\author{
Ayça Biçen (D), Nazlı Güvenç (D)
}

Kansai Altan Boya Sanayi ve Ticaret A.Ş. Ankara Asfaltı 25.km - 35730 Kemalpaşa, Izmir

Geliş / Received: 04/06/2021, Kabul / Accepted: 31/07/2021

\begin{abstract}
In general, coatings are specified as organic or inorganic according to their chemical structure. They might be used for decoration and protection purposes on several materials, or as assemblies to cover substrates. The combination of materials in a coating must provide durability under all conditions, however surface defects might occasionally occur on coated objects. Crater formation on the coated surface is the most common issue in the coating industry. The root-cause of crater formation remains unclear in several cases, and complex analysis is required for its identification. The combination of SEM-EDX and FT-IR microscopy methods might be promising for the analysis of organic and inorganic components of a coating. In this study, a water-borne primer coating applied on a tin surface, and a comparison analysis was performed at an area with crater defect and at a defect-free reference area both observed on the same coated panel. As a consequence, it has been found that the concentration of Calcium element, derived from Calcite in coating, was higher in the crater area than the reference area. For further analysis, another inorganic component $\mathrm{TiO}_{2}$ was compared to $\mathrm{CaCO}_{3}$ through the comparison of proportions of $\mathrm{Ca}$ and $\mathrm{Ti}$ elements to $\mathrm{C}$ element. All visual and quantitative data obtained from these techniques indicate agglomeration of Calcite on the crater area. The methods applied in this study might assist on the identification of root-cause of crater formation on coatings and offer a new perspective to resolve several kinds of surface defects that coating industry suffers from.
\end{abstract}

Keywords: Organic Coating, Surface defect, SEM-EDX, FT-IR Microscopy, Crater Formation

\section{SEM-EDX ve FT-IR Mikroskop Yöntemleri ile Boya Kaplamalarında Krater Oluşumunun İncelenmesi}

\section{Öz}

Boya kaplamaları, genellikle kimyasal yapılarına göre organik veya inorganik içerikli olarak sinıflandırılmaktadır. Malzeme üzerinde dekorasyon ve koruma amacıyla veya yüzeyleri kaplamak için kullanılabilirler. Boya kaplamalarındaki malzemelerin içeriği her koşulda dayanıklılık sağlamalıdır. Ancak, bazen boya kaplaması uygulamaları sonrasında yüzeylerde kusurlar meydana gelebilir. Boya kaplamaları sektöründe en sık karşılaşılan sorun kaplanmış yüzeyde krater oluşumudur. SEM-EDX ve FT-IR mikroskop yöntemlerinin birlikte kullanılması, boya kaplamalarının organik ve inorganik bileşenleri kaynaklı krater oluşumunun tespiti için umut verici olmaktadır. Bu çalışmada, su bazlı astar kaplanmış kalay panel üzerinde gözlemlenen krater problemi ile referans yüzey arasında SEM-EDX ve FT-IR mikroskop yöntemleri birlikte kullanılarak kök neden analiz çalışmaları gerçekleştirilmiştir. Sonuç olarak, boya kaplamasındaki kalsit ham maddesi kaynaklı kalsiyum elementinin konsantrasyonunun krater alanında referans alana göre daha yüksek olduğu tespit edilmiştir. Sorunlu ve referans yüzeylerin EDX analizinde tespit edilen Ca ve Ti elementleri içeriğinin C elementi içeriğine olan oranları karşılaştırıldığında, inorganik kompozisyon oranlarındaki değişimi

*Corresponding Author:ayca.bicen@kansaialtan.com.tr 
desteklemektedir. Bu yöntemlerden elde edilen tüm nicel ve nitel veriler, kalsit'in krater alanında aglomere olduğunu göstermektedir. Bu çalışmada uygulanan SEM-EDX ve FT-IR mikroskop analitik yöntemleri kombinasyonunun organik ve inorganik yapıların krater oluşumuna etkisini belirlemek amacıyla kullanılması, boya kaplamalarında krater oluşumunun temel nedeninin belirlenmesine yönelik çalışmalara yardımcı olabileceği düşünülmektedir. Böylece bu iki analitik yöntem, boya endüstrisinin sıklıkla karşılaştığı organik veya inorganik kaynaklı çeşitli yüzey kusurlarını çözmek için yeni bir bakış açısı sunmaktadır.

Anahtar kelimeler: Boya Kaplamaları, Yüzey kusurları, SEM-EDX, FT-IR Mikroskop, Krater Oluşumu

\section{Introduction}

All coatings contain a film-forming material which can be organic and inorganic. They are commonly used for protection from corrosion or to provide a pleasing appearance on the coated surface. They can be either in a clear form or filled with a variety of different pigments, depending on the function. Therefore, coatings must be made microscopically homogenous and different combinations of coatings must be resistant to the damaging effects of diverse environmental conditions. Unfortunately, failures and surface defects might emerge at various times in the life of a coating. Coatings are susceptible to a variety of defects such as craters, dewetting, telegraphing, soak-in, pinholes, orange peel, sagging, air entrapment, and color changes. Even though identification of surface defects is occasionally straightforward, type of the defect or the coating commonly renders it complex and challenging (A. Bhatia,1995).

Craters are one of the most common surface defects and their root-cause is highly complex to be identified. Craters generally emerge when the coating contains low surface tension materials causing a depression on the surface and leaving circular defects with different sizes and shapes on the final product. Insufficiently homogenized low-surface tension ingredients or those exposed to low-surface tension contaminants may result in crater formation through substrate dewetting (C.K. Schoff,1999). During the formation of a crater, surrounding coating material does not completely move away, yet causes the formation of a slightly raised circular frame around the point of depression, thus a microscopic shape resembling a volcanic crater is formed. Craters are formed in a variety of shapes and sizes such as shallow type, fisheye type, and small pinholes. Complex analysis tools are required to study crater formation on the coating surface, since the human eye might cause inaccurate findings. Even powerful analytical instruments yield insufficient results for the identification of root-cause of the defected area as it might be caused by several sources (B. Fitzsimons and T. Parry, 2011 and Kenneth B. Tator,2015).

Light microscopy was used as a powerful technique for the examination of the source of crater formation previously. Recently, Scanning Electron Microscopy (SEM) and its attached X-ray spectrometer (EDX) have been found to be sufficient techniques for the identification of both the defects on a surface and its related elements. SEM equipped with field emission gun (FEG), greatly increases the spatial resolution in microscopic observations for the examination of the surface characterization of a coating film. Besides chemical analysis of inorganic components in the coating is possible with SEM coupled with Energy Dispersive X-ray Spectroscopy (EDX) (Q. Luo, 2018).

On the other hand, Infrared spectroscopy has been frequently used to identify chemical structures of coatings. In IR technology, further methods such as Reflectance or Attenuated Total Reflectance (ATR) are eligible if the sample is too bulky or is in powder or solid form. 
Furthermore, Fourier Transform Infrared (FT-IR) microscopy offers an alternative analytical approach for the imaging of coating surfaces as it is capable of efficiently measuring small areas in the coating. FT-IR provides spatially resolved acquisition of infrared spectra that reveals detailed information on the organic functional group distribution through the defected area to the reference area. Hence, it can be used as a complementary technique to investigate organic components on the coating film in case the defect does not only arise from the inorganic component (J. Van Der Weerd, 2001).

This study aims the characterization of craters observed on the surfaces of coated panels via SEM-EDX and FT-IR microscopy and investigation of the root-cause of crater formation on coated panels. The origins of crater formation were determined by the interpretation of results from these two instrumental techniques. Still, since the crater formation is caused by various parameters on different surfaces, further studies might be required to explore the root-cause of crater formation from different sources.

\section{Experimental}

\subsection{Materials and Methods}

The coating used for this study consists of a one-component system which contains epoxy ester resin as a polymer and mainly water as a solvent. The prepared coating was applied on tin panel with dipping method, and it was thermally cured at $140{ }^{\circ} \mathrm{C}$ for 20 minutes. During the quality control inspections performed on the surface of coated panel, a defected area similar to crater was observed. Afterwards, all panels were cut to a dimension of $1 \mathrm{x} 1 \mathrm{~cm}$ for FT-IR microscopy and SEM-EDX analysis. The area of the crater formation was examined and compared with the reference area.

\subsection{FT-IR Microscopy Analysis on the Crater Area}

Infrared spectroscopy is frequently used to identify organic compounds in a coating. In FT-IR microscopy technique, a combination of standard visible light microscopy and IR spectroscopy provides a different approach that can be used with different sampling modes such as reflectance or attenuated total reflectance (ATR) at room temperature or cooled environment for the characterization of the coated surface. The possibility of detecting a small, defected area on the coating is increased by FT-IR microscopy. For this purpose, FT-IR microscope Thermo Nicolet iN10 equipped with ATR facility was used in this study.

\subsection{FEG-SEM, EDX Analysis on the Crater Area}

For the identification of the crater formation on coated panels, Scanning Electron Microscopy (SEM) measurements were performed by attaching Energy Dispersive X-ray (EDX) to the system and elements present in the coating were identified. SEM measurements were carried out on a Carl Zeiss Gemini 300 Series and the elemental analysis and mappings were performed with EDAX EDX detector. Before SEM-EDX analysis of the samples, the crater defected panel and the reference panel were coated with a layer of gold to improve the image quality and increase the low conductivity of the sample, thus preventing accumulation of charge by using Quorum Q 150R ES plus. Images and EDX measurements were performed at different magnifications that are indicated on the images and accompanied by a scale bar. 


\section{Results and discussion}

\subsection{FT-IR Microscopy Characterization}

FT-IR microscopy is a well-established method for the chemical identification of particles or contaminants and for the visualization of the distribution of certain substances in complex compounds. Crater areas on the surface of coated panel were analyzed and compared to the reference area. As shown in Figure 1, crater area was clearly observed by IR imaging system and compared to the reference area. Afterwards, line and point map analysis were performed by ATR attachment. For the determination of structural differences, which might originate from environmental contaminations or coating components, defective area and reference area were comparatively examined.

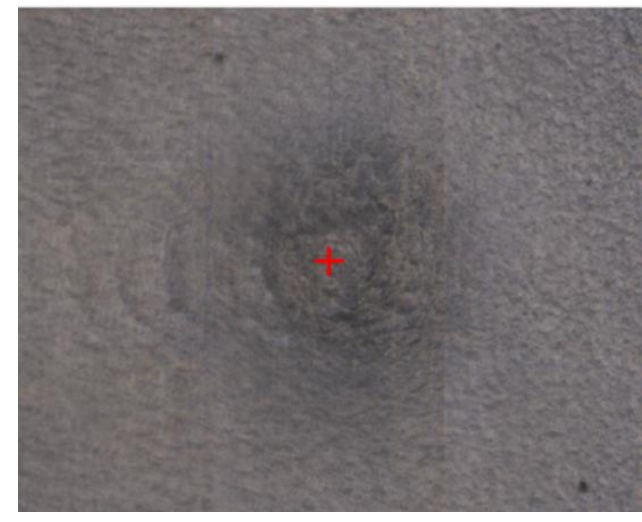

(A)

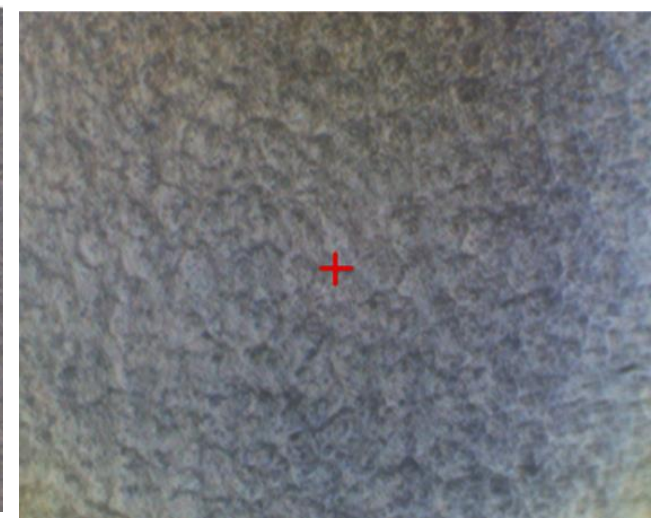

(B)

Figure 1. FT-IR microscope images of the crater area (A) and reference area (B).

In Figure 2, line map analysis of the crater area is shown. The spectra collected in line map of crater area and reference area were analyzed in the matter that catches the best difference between the compared areas. The overlay of the spectrums showed that collected data around crater region was reproducible. Furthermore, alteration of the intensity between spotted regions in line map were shown in Figure 2.

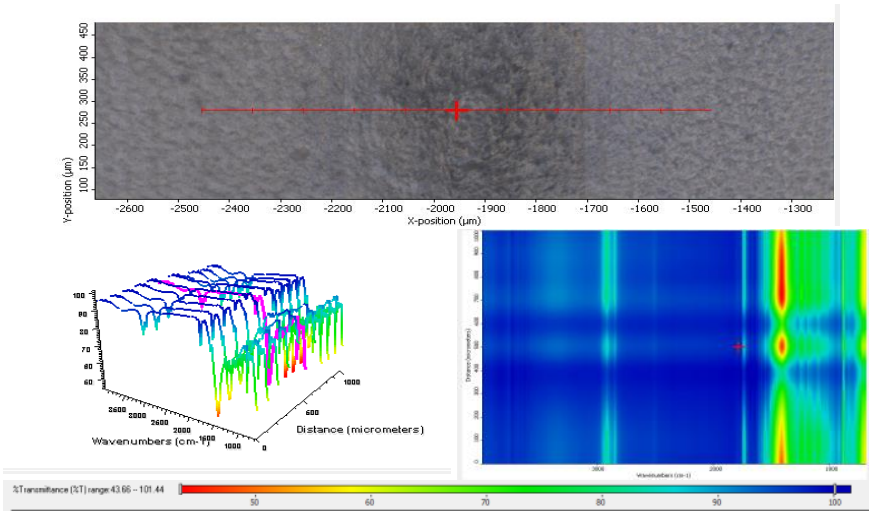

Figure 2. Line map data of the crater area. 
FT-IR spectrum of each point were obtained by line mapping for the crater area, as shown in Figure 3. According to baseline corrected FT-IR spectrum results shown in Table 1, it was determined that the ratio of the $\mathrm{CaCO}_{3}$ derived from $\mathrm{Ca}-\mathrm{CO}_{3}$ stretching at $1410 \mathrm{~cm}^{-1}$ to ester bond derived from $\mathrm{C}=\mathrm{O}$ stretching at $1730 \mathrm{~cm}^{-1}$ in the spectra was higher for the crater area than the reference area. Consequently, it might be concluded that the ratio of $\mathrm{CaCO}_{3}$ is getting higher towards the crater area.
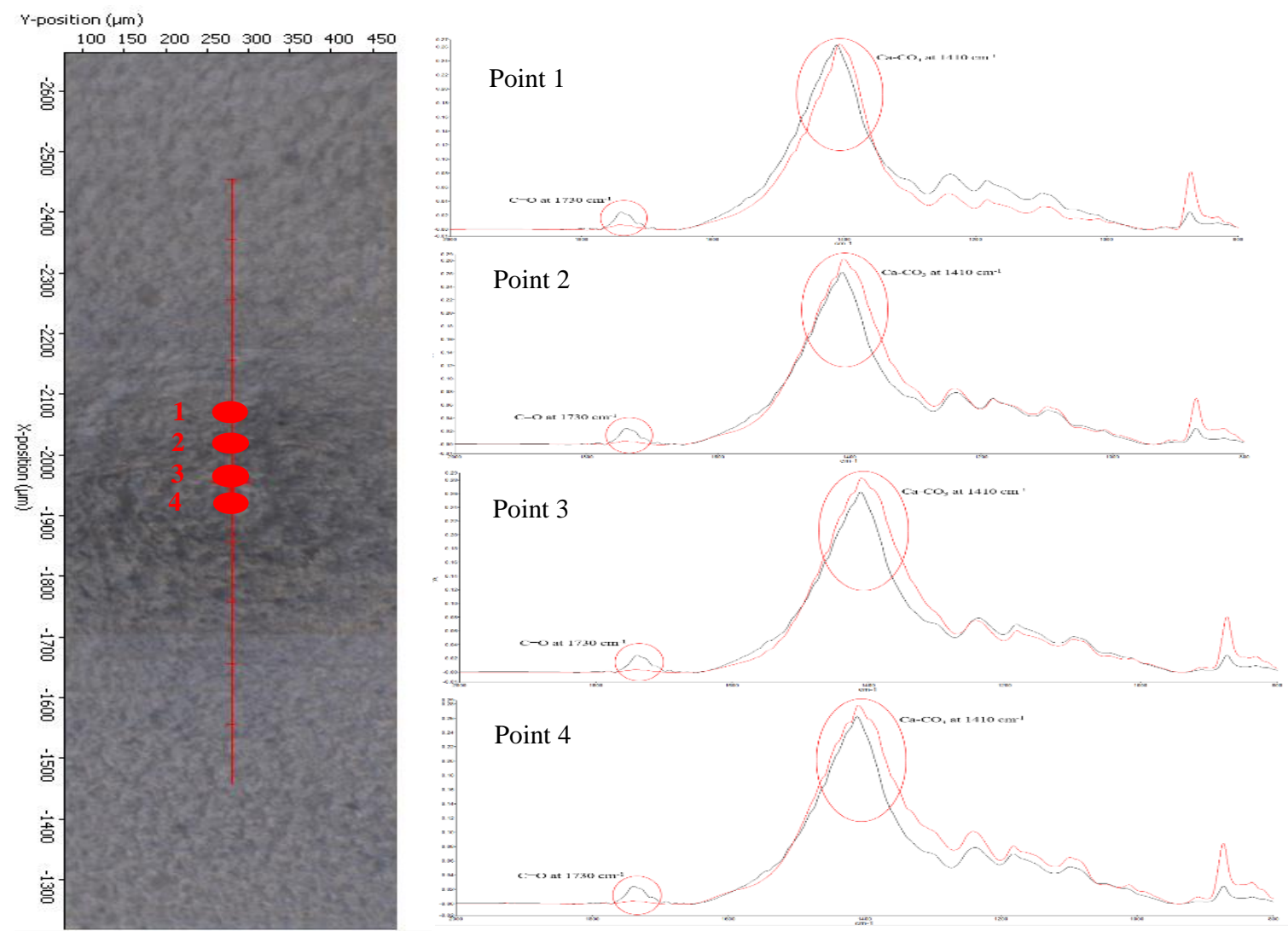

Figure 3. FT-IR spectra comparison of chosen spectra from line map. The spectra of the crater areas are shown in red and the spectra of the reference areas in black.

Table 1. The Evaluation of FT-IR Microscopy Analysis Results

\begin{tabular}{|c|c|c|c|c|c|}
\hline \multicolumn{6}{|c|}{ Evaluation of FT-IR Microscopy Analysis Result } \\
\hline \multirow{2}{*}{$\begin{array}{c}\text { Name of Streching / } \\
\text { Absorbance }\end{array}$} & \multicolumn{4}{|c|}{ The Crater Area } & \multirow{2}{*}{$\begin{array}{c}\text { The Reference Area } \\
\text { Point } 1 \\
\end{array}$} \\
\hline & Point 1 & Point 2 & Point 3 & Point 4 & \\
\hline $\mathrm{Ca}-\mathrm{CO}_{3}$ & 0.2635 & 0.2821 & 0.2829 & 0.2782 & 0.2626 \\
\hline$C=0$ & 0.0070 & 0.0048 & 0.0038 & 0.0035 & 0.0246 \\
\hline Rate of $\mathrm{Ca}-\mathrm{CO}_{3}$ to $\mathrm{C}=\mathrm{O}$ & 37.6429 & 58.7708 & 74.4474 & 79.4857 & 10.6728 \\
\hline
\end{tabular}




\subsection{SEM-EDX Analysis}

Firstly, SEM analysis of the crater area on the coated panel was performed. Then, the elemental content of the crater area was determined by using full scan, point scan and mapping methods with the support of EDX analysis. Mapping analysis provides visual observation of alterations of the elements that are analytically determined on the crater area.

The SEM image comparison of the crater area and the reference area is shown in Figure 4. Crater formation on the surface of coated panel was clearly observed. EDX analysis determined the ratio of $\mathrm{Ca}$ element to be higher in the crater area than the reference area.

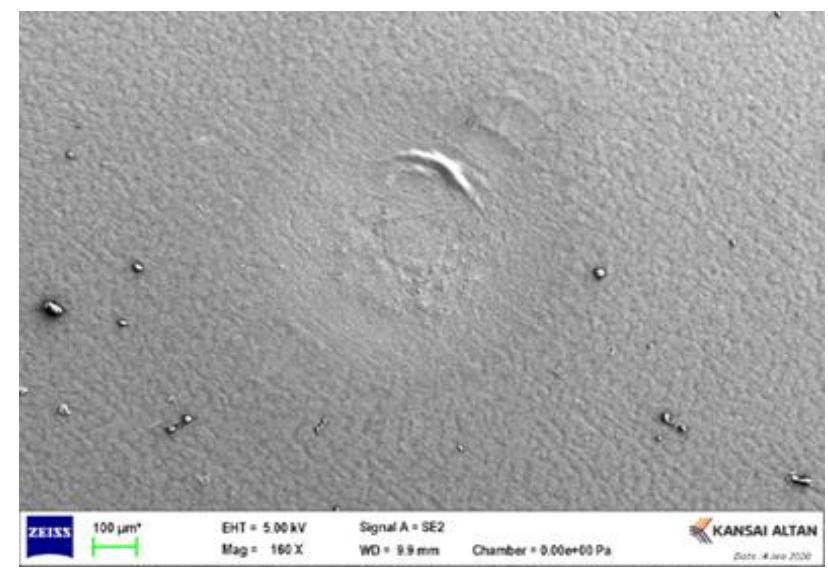

(A)

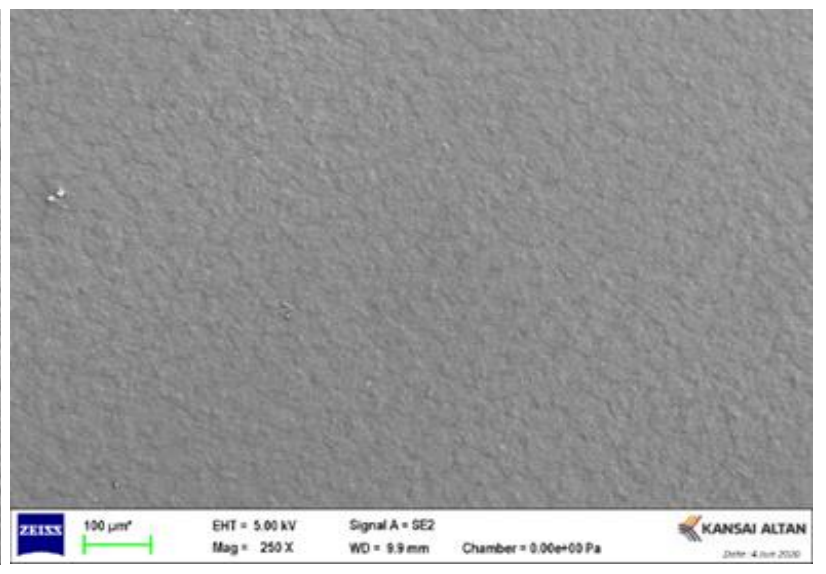

(B)

Figure 4. Comparison of images that belong to crater area (A) and reference (B) respectively.

It might be concluded that this result originates from the agglomeration of the calcite that is involved in the coating formulation. On the other hand, no trace of contamination was found on the surfaces. EDX results with different methods such as full scan, point scan and mapping of the crater area are shown in Figure 5 and EDX results of the reference area are shown in Figure 6. In order to investigate the reproducibility of the data, crater and reference areas that were scanned with different methods were compared according to the ratios obtained from the EDX results. 

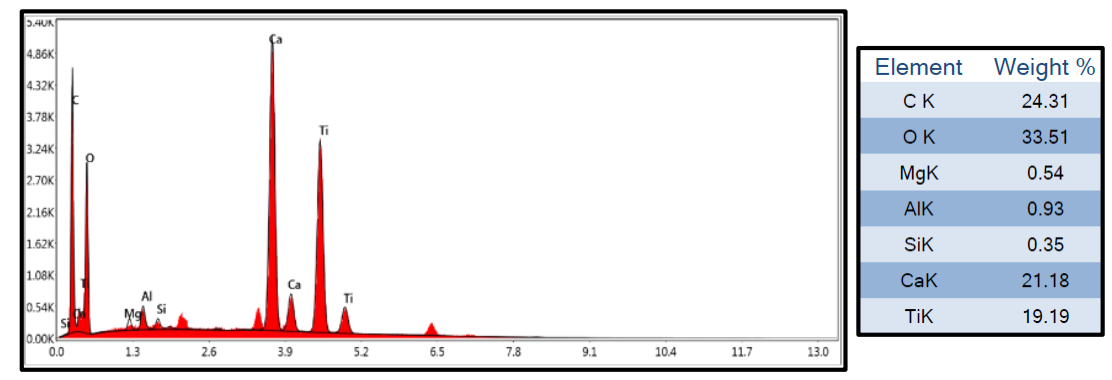

(A)
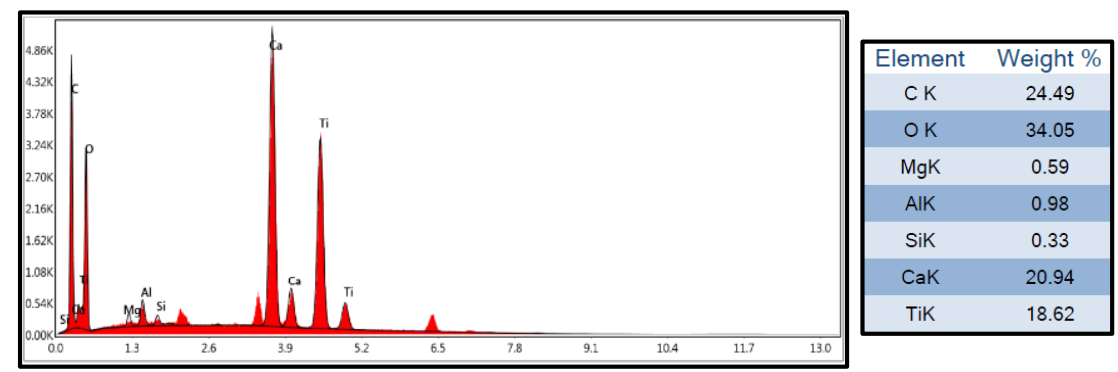

(B)
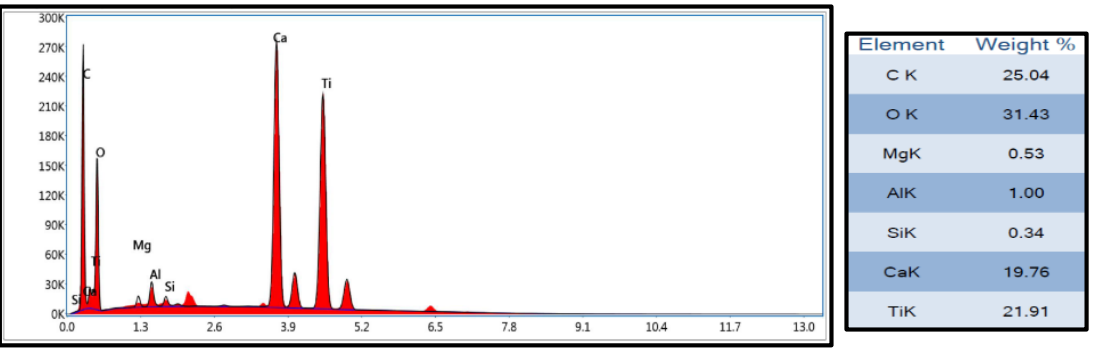

(C)

Figure 5. Full scan (A), point scan (B) and mapping (C) EDX results of the crater area, respectively.
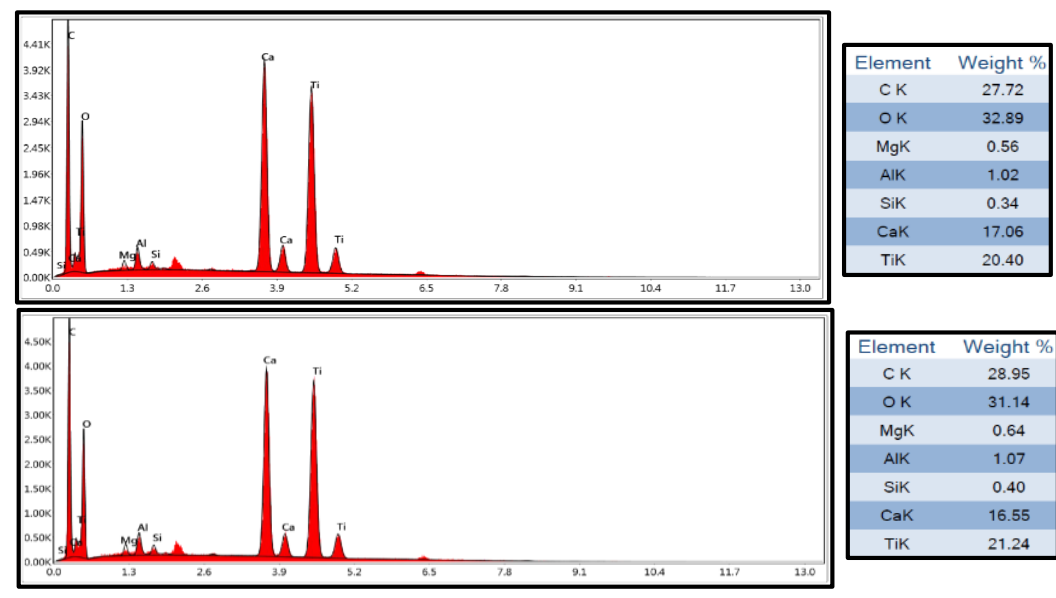

(A)

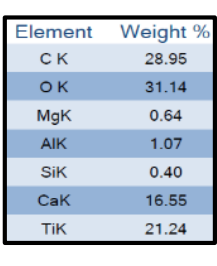

(B)
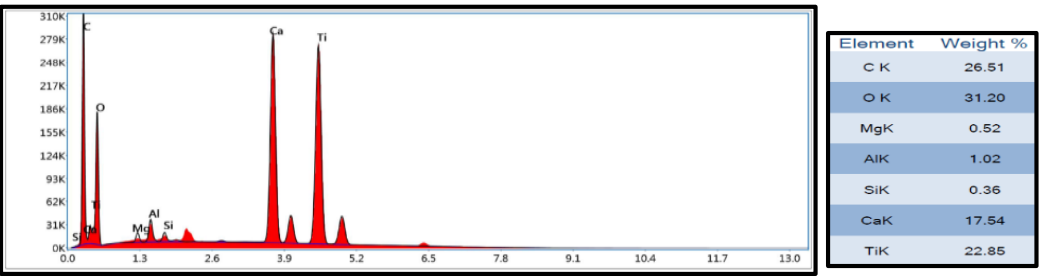

(C)

Figure 6. Full scan (A), point scan (B) and mapping (C) EDX results of the reference area, respectively. 
The reproducibility between the crater and the reference area was generated based on EDX results. Summative assessment of EDX results for each sample were shown in Table 2.

Table 2. Summative Assessment of EDX Results for the crater and the reference areas.

\begin{tabular}{l|l}
\hline Sample Name & $\mathrm{C}-\mathrm{O}-\mathrm{Al}-\mathrm{Ca}-\mathrm{Mg}-\mathrm{Si}-\mathrm{Ti}$ \\
\hline Reference - Full Scan & $\mathrm{C}-\mathrm{O}-\mathrm{Al}-\mathrm{Ca}-\mathrm{Mg}-\mathrm{Si}-\mathrm{Ti}$ \\
Reference - Point Scan & $\mathrm{C}-\mathrm{O}-\mathrm{Al}-\mathrm{Ca}-\mathrm{Mg}-\mathrm{Si}-\mathrm{Ti}$ \\
Reference - Mapping & $\mathrm{C}-\mathrm{O}-\mathrm{Al}-*^{*} \mathrm{Ca}-\mathrm{Mg}-\mathrm{Si}-\mathrm{Ti}$ \\
The Crater Full Scan & $\mathrm{C}-\mathrm{O}-\mathrm{Al}-*^{*} \mathrm{Ca}-\mathrm{Mg}-\mathrm{Si}-\mathrm{Ti}$ \\
The Crater Point Scan & $\mathrm{C}-\mathrm{O}-\mathrm{Al}-*^{*} \mathrm{Ca}-\mathrm{Mg}-\mathrm{Si}-\mathrm{Ti}$ \\
The Crater Mapping &
\end{tabular}

In addition to comparison of $\mathrm{Ca}$ element content between the crater and reference areas, evaluation of the ratio of $\mathrm{Ca}$ element in organic matrix is critical for the finding of agglomeration of calcite in the coating formulation. For this reason, the ratio of $\mathrm{Ca}$ element and $\mathrm{Ti}$ element that are participating in Calcite and $\mathrm{TiO}_{2}$ content of coating to $\mathrm{C}$ element that is derived from organic matrix were compared. Results are shown in Table 3 . According to Table 3 , the evaluation of $\mathrm{Ca}$ content in organic matrix was found to be $0.87,0.85$ and 0.79 respectively in the crater area and $0.61,0.57$ and 0.66 respectively in the reference area. This indicates that while $\mathrm{Ca}$ element content is higher in the crater area, there is not significant difference of $\mathrm{Ti}$ element content between the crater and reference areas.

Table 3. The ratio of $\mathrm{Ca}$ and $\mathrm{Ti}$ elements to $\mathrm{C}$ element as the organic matrix.

\begin{tabular}{c|c|c|c|c|c|c}
\hline \multicolumn{4}{c}{ Evaluation of EDX Analysis Result } \\
\hline \multirow{2}{*}{ Rate of Elements } & \multicolumn{3}{c|}{ The Crater Area } & \multicolumn{3}{c}{ The Reference Area } \\
\cline { 2 - 7 } & Full Scan & Point Scan & Mapping Scan & Full Scan & Point Scan & Mapping Scan \\
\hline $\mathrm{Ti} / \mathrm{C}$ & 0.79 & 0.76 & 0.87 & 0.73 & 0.73 \\
$\mathrm{Ca} / \mathrm{C}$ & 0.87 & 0.85 & 0.79 & 0.61 & 0.56 & 0.66 \\
\hline
\end{tabular}

Regarding the results of SEM-EDX evaluations, mapping analysis of the crater panel and reference panel were performed to visualize agglomeration of Calcite in crater surfaces (Shown in Figure 7). 

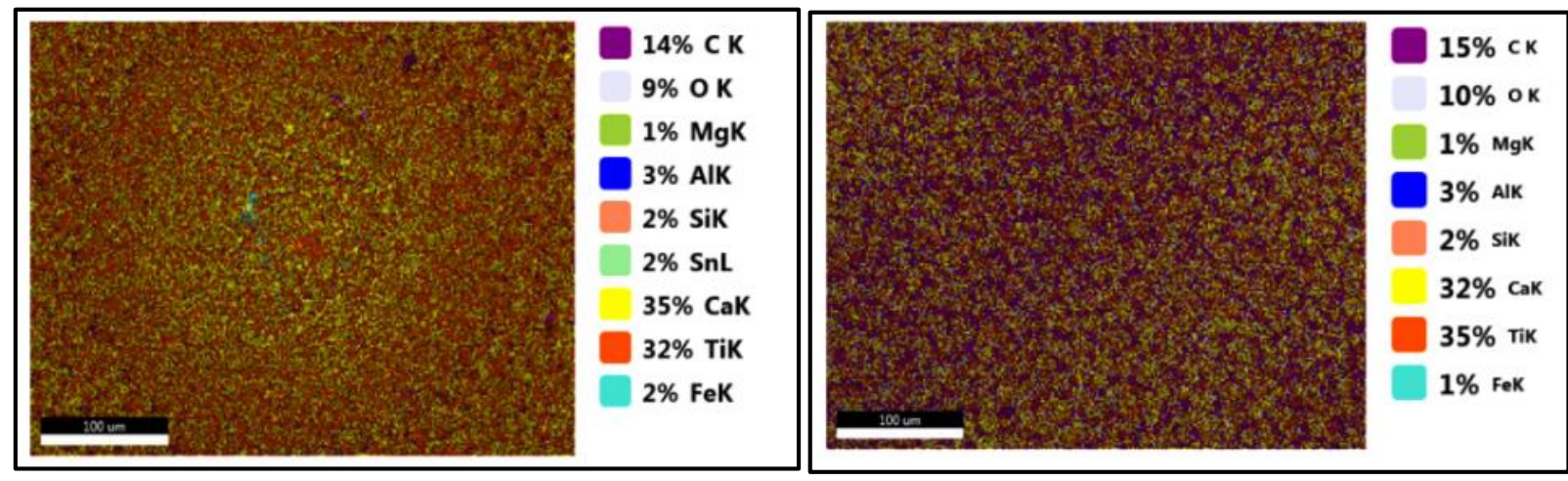

Figure 7. Overlay images of the crater area and the reference area, respectively.

In the mapping results shown in Figure 7, different colors were assigned to each element and overlay images were obtained with respect to overlapping elemental content of individual elements. The percentages of each element indicated on the images are based on their Region of Interest (ROI) value. These values show the total element count in the mapping image, and each color shows the distribution of related element with this count in the image area. Although the count of $\mathrm{Ca}$ element between the crater area and reference area are similar, visual results obtained from mapping indicate that the ratio of Ca element (shown in yellow) is higher in the crater region than that of the reference. Consequently, it might be concluded that this finding and SEM-EDX analysis support each other.

\section{Conclusions}

In this study, both SEM-EDX and FT-IR microscopy analyses were performed for the investigation of the root-cause of defect on the coated panel. Optimization of the SEM-EDX and FT-IR methods, enabled the investigation of every component of the coated panel that could cause crater defect. These methods showed the agglomeration of Calcite, which is an inorganic component of the coating, on the crater area. In conclusion, combination of different analysis techniques for the determination of root-cause of crater formation led up to the evaluation of both organic and inorganic components of the coating systems, which was a complex issue to be solved. Further analysis might provide improvements in coating industry enabling the elimination of defects.

\section{Acknowledgements}

The authors are grateful to Kansai Altan Boya Sanayi ve Ticaret A.Ş., for their support during this work.

\section{References}

A. Bhatia and B.E.,(1995) Coating Types and Characteristics, Chapter 4, Pdhonline.

C.K. Schoff (1999), Surface Defects: Diagnosis and Cure, Protective Coatings.

B. Fitzsimons and T.Parry (2011) Fitz's Atlas 2 of Coating Defects, MPI Group. 
Kenneth B. Tator (2015), ASM Handbook Volume 5B: Protective Organic Coatings, ASM International.

Q.Luo (2018), Electron Microscopy and Spectroscopy in the Analysis of Friction and Wear Mechanisms, Lubricants.

J. Van Der Weerd, H. Brammer, J. J. Boon, and R. M. A. Heeren (2001), Fourier Transform Infrared Microscopic Imaging of an Embedded Paint Cross-Section, Society for Applied Spectroscopy. 